\title{
Operations of the Federal Reserve Bank
}

\section{of St. Louis - 1967}

\begin{abstract}
HE FEDERAL RESERVE BANK of St. Louis, in addition to responsibilities involving national monetary policy, performs commercial bank supervisory functions and a variety of services for the public, the United States Government, and commercial banks. Analyses of economic developments providing background information on monetary actions are frequently presented in this Review, with an analysis of the entire year 1967 contained in the December issue. This report of the past year's operations concentrates on the service and other functions of the bank.

The activities of the Federal Reserve System are carried out through twelve Federal Reserve Banks and their twenty-four branches and through central coordination by the Board of Governors in Washington. Following the Federal Reserve Act of 1913, creating the Federal Reserve System, the country was divided into twelve Federal Reserve Districts. Each of these districts contains a Federal Reserve Bank, and ten of the Banks have one or more branches. The territory of the Eighth Federal Reserve District includes all of Arkansas and portions of Illinois, Indiana, Kentucky, Mississippi, Missouri, and Tennessee. In addition to the head office, the Federal Reserve Bank of St. Louis maintains branch offices in Little Rock, Louisville, and Memphis. The transactions of these four offices are primarily with banks and businesses in the zone territories of the particular office.
\end{abstract}

\section{Service Operations}

Among its service operations the four offices of this bank furnish currency for circulation, maintain facilities for the collection and clearing of checks, handle the legal reserve accounts of member banks, and act as fiscal agent of the Government. Most operations at the bank's offices increased in 1967, reflecting growth

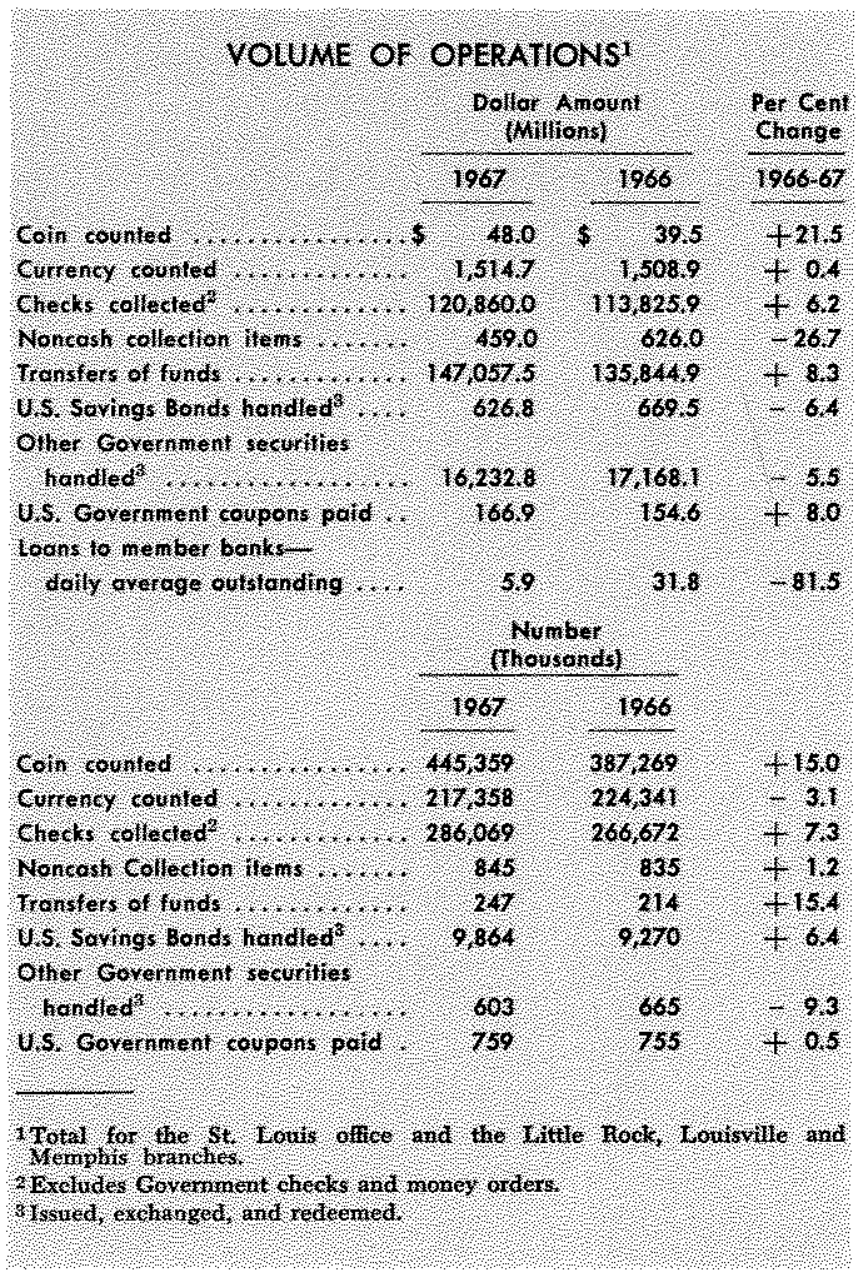


in economic activity in the Central Mississippi Valley. ${ }^{1}$

\section{Money Operations}

Supplying coin and currency to commercial banks, and thereby to the general public, is carried out through the Money Department at each of the four offices of this bank. Member banks obtain coin and currency from Reserve Banks by withdrawals from their accounts at the Reserve Banks. Nonmember banks may obtain coin and currency from member banks or directly from Reserve Banks, with charges made to a designated member bank's reserve account. When banks receive an excess of coin and currency from their customers, it is deposited in the Federal Reserve Bank, where it is sorted and counted and the usable money is redistributed.

Coin handling in 1967 continued the sharp rise experienced in the previous two years. The number of pieces counted rose from a low of 227 million in 1964 (reflecting a severe coin shortage) to 445 million in 1967, an average annual increase of 25 per cent. Meanwhile, the dollar value increased at a similar rapid rate, rising from $\$ 24.5$ million to $\$ 48$ million. Following the 1961-64 decline in coin operations, both number and dollar value of coins handled in 1967 approached the 1961 peak when 490 million coins valued at $\$ 48.3$ million were counted.

The dollar value of currency handled during 1967

1 For an analysis of economic activity of the region during 1967 , see the January 1968 issue of this Review.

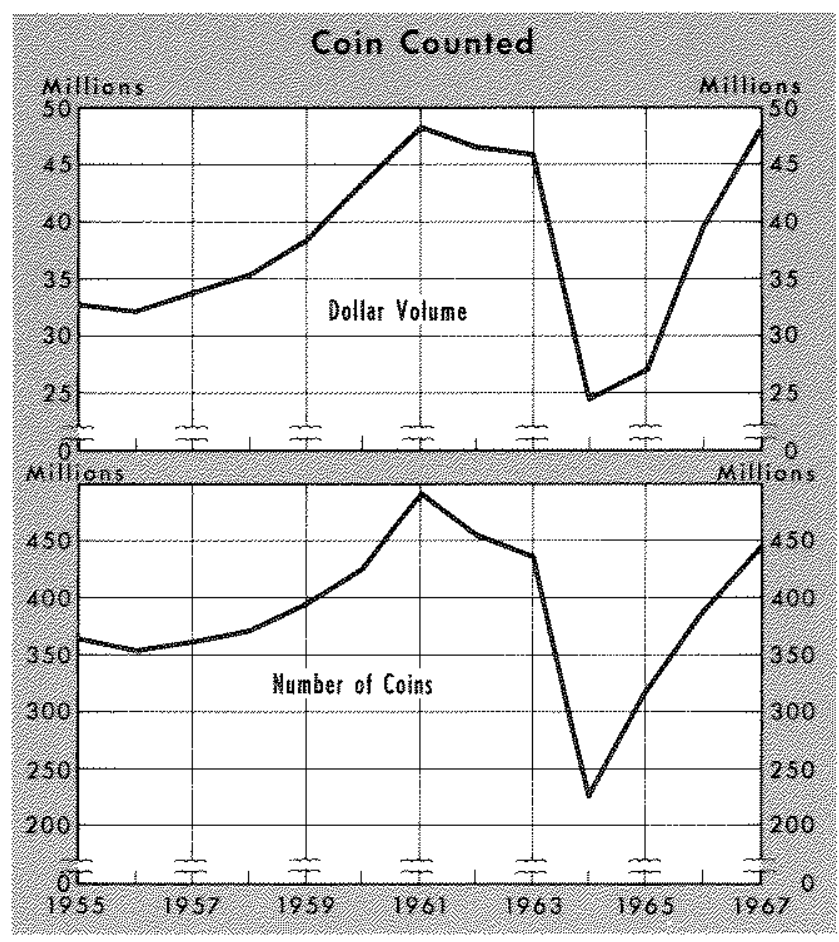

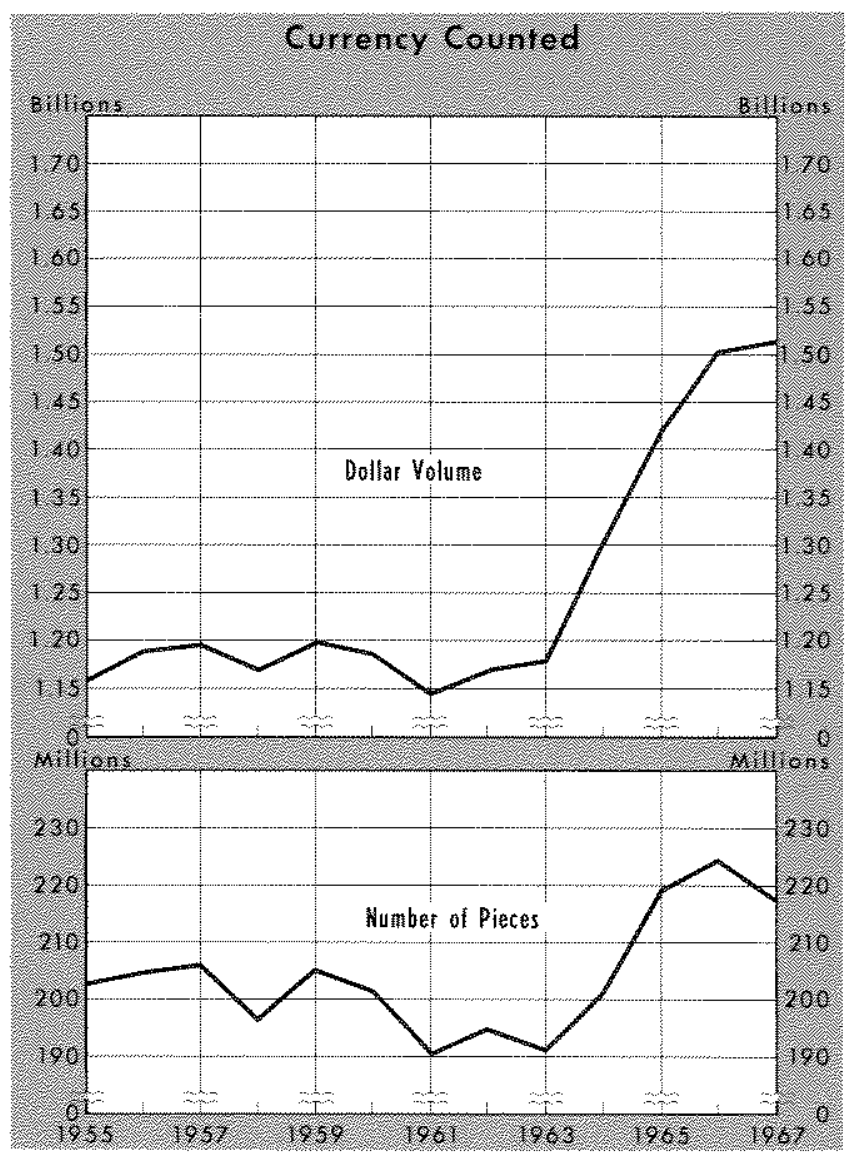

was $\$ 1.5$ billion, about unchanged from the previous year. The value of currency counted increased sharply from 1963 to 1966, following a period of virtually no change during the previous eight years. The number of pieces counted totaled 217 million in 1967,3 per cent less than a year earlier.

\section{Check Collections}

Federal Reserve Banks collect checks and provide a mechanism through which commercial banks settle for the checks collected. This facilitates the use of demand deposits by individuals, businesses, and governments in making payments. The four offices of this bank receive checks from district member banks, other Federal Reserve offices, and Government agencies for collection. In oxder to increase the promptness of collections, the Reserve Bank in some cases receives checks directly from member banks in other Federal Reserve Districts. Checks received are drawn on banks in the Eighth District that remit at par, ${ }^{2}$ par-remitting

2All checks collected and cleared through the Federal Reserve Banks must be paid in full by the banks on which they are drawn, without deduction of a fee or charge; that is, they must be payable at par. National banks and state member banks must remit at par as a condition of membership. In addition, most state non-member banks agree to remit at par. 


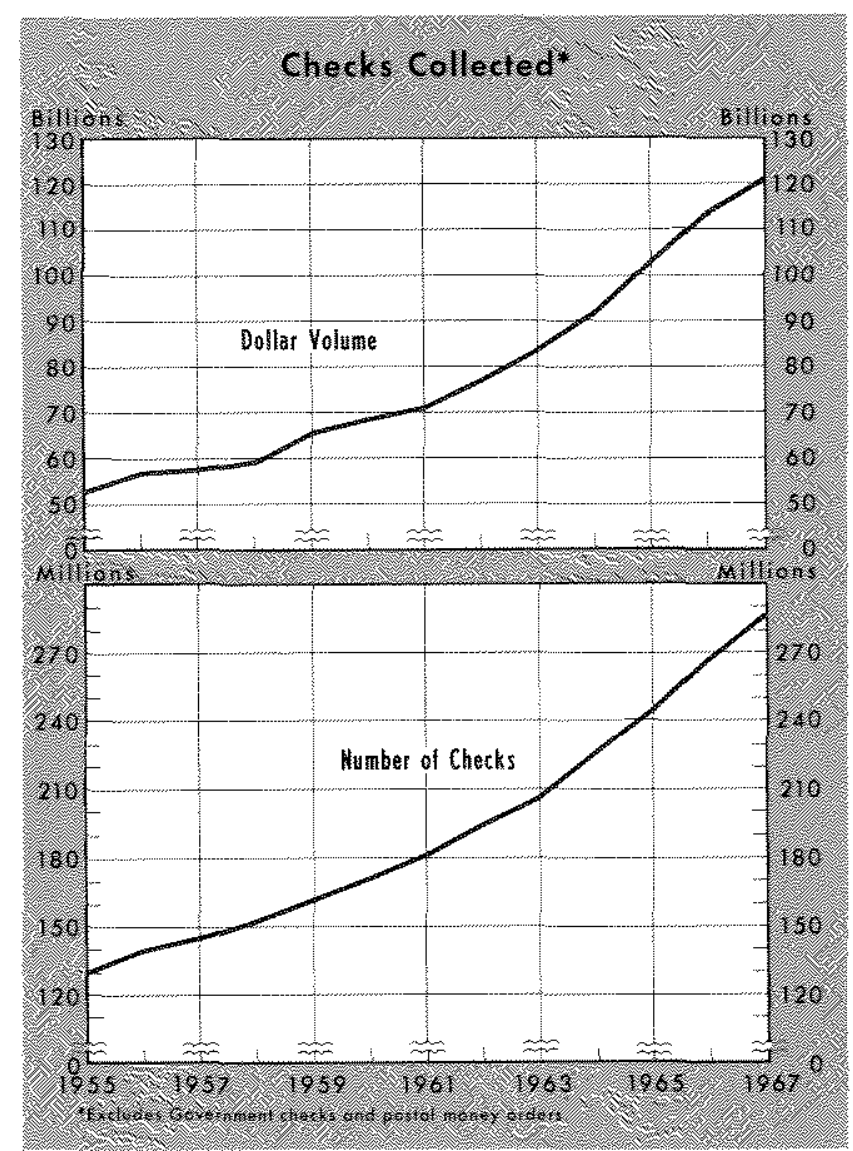

banks in other districts, Federal Reserve Banks, and the United States Treasury.

The number of checks passing through the four offices of this bank rose from 267 million in 1966 to 286 million in 1967, an increase of 7.3 per cent. The dollar value of these collections rose 6.2 per cent to $\$ 121$ billion.

The Little Rock branch, after moving into a newlyconstructed building last year, installed high-speed computers for check processing operations. Following this installation, all offices now employ high-speed electronic check processing equipment.

A major step toward completely automated check handing occurred with the announcement that, beginning September 1, 1967, checks cleared through any Federal Reserve Bank must have the routing symboltransit number of the bank on which it is drawn imprinted in MICR (Magnetic Ink Character Recognition) encoding.

Since the September deadline if the routing symboltransit number does not appear in magnetic ink on the check prior to receipt by the Federal Reserve Bank, it may be treated as a noncash item. Noncash items are not processed as quickly because special handling is required. Also, the sending bank does not receive credit for it until the Federal Reserve Bank receives payment from the bank on which the check was drawn, resulting in a longer collection time.

Following the effective date of the encoding requirements, the number of nonconforming items in the St. Louis district has dropped sharply. From an average of 6.4 per cent of the checks received at the St. Louss bank and its branches in the spring of 1967, the number of checks not bearing the routing symbol-transit number had dropped to less than 0.2 per cent by the close of the year.

\section{Noncas Collecthons}

In addition to maintaining facilities for check collections, Federal Reserve Banks handle numerous other items for collection. Referred to as noncash collections, these include drafts, promissory notes, bonds and bond coupons, and various other documents. The combined dollar value of these collections was down 27 per cent from 1966 to 1967 , although the number of items rose 1 per cent.

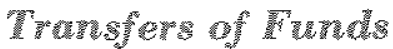

Wire transfers of funds are largely movements

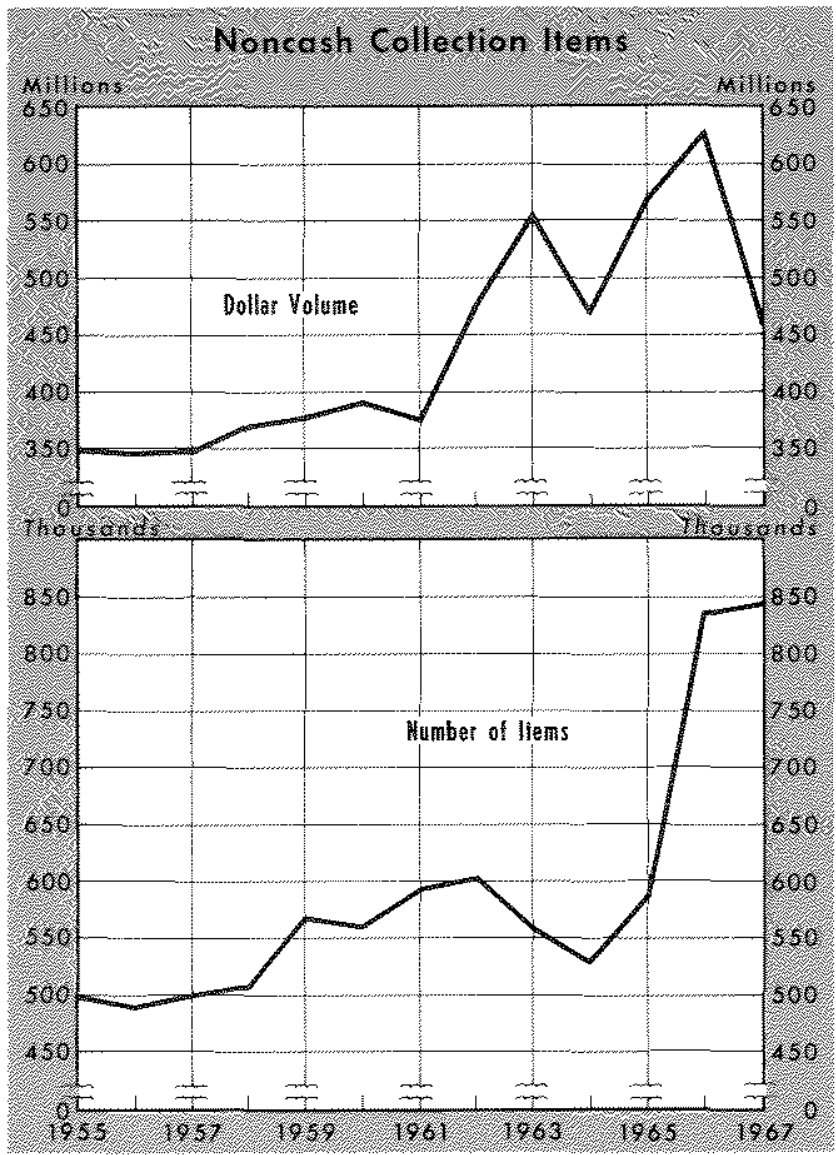




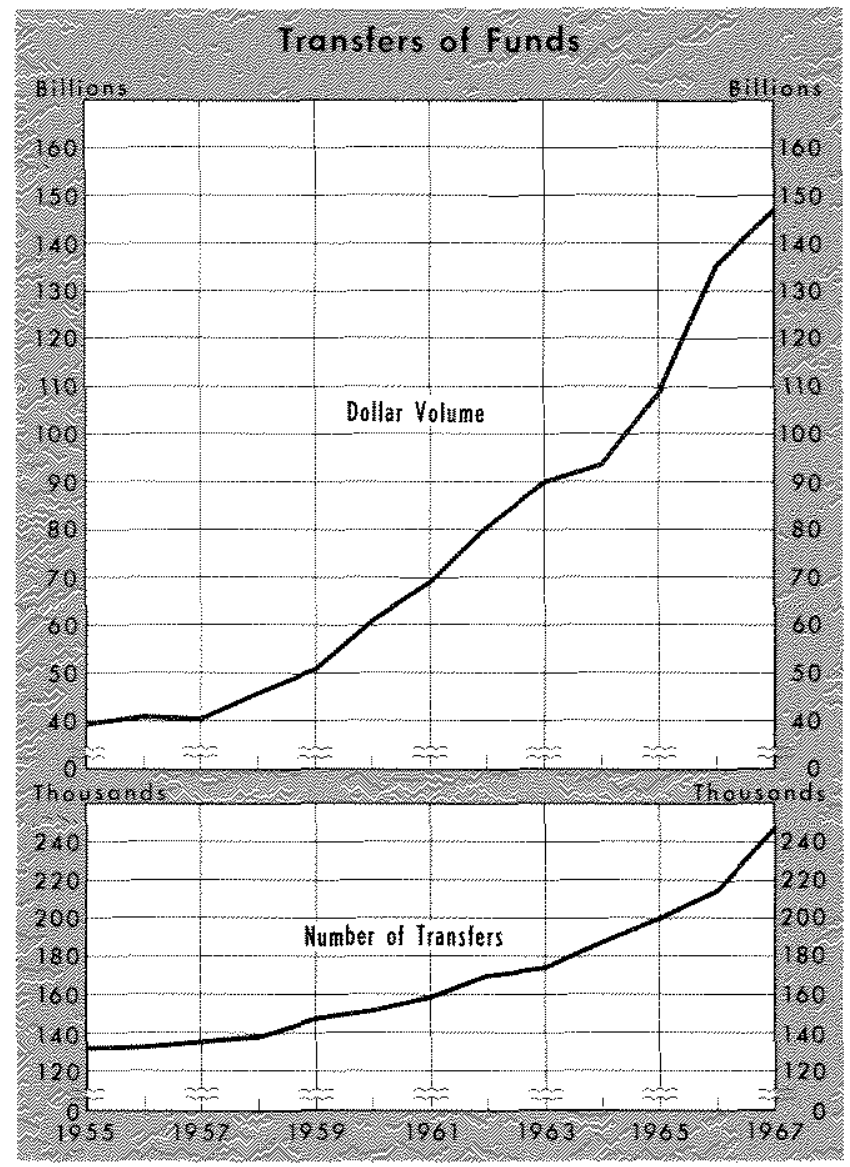

of member bank balances between Federal Reserve Banks. Such transfers result primarily from Federal funds transactions, check collection settlements, and transfers in connection with transactions in U. S. Treasury obligations. In recent years the volume of such transfers has risen sharply. This bank participated in 247 thousand such transfers in 1967, up 15 per cent from the previous year. The dollar value, totaling $\$ 147$ billion, was up 8 per cent. Since 1957 the number of these transfers has risen at an average annual rate of 6 per cent, while dollar volume has risen 14 per cent yearly.

\section{Wiscal Agency Operthons}

Each Federal Reserve Bank acts as depository and fiscal agent of the United States Government. The Reserve Banks carry the principal checking accounts of the Treasury, issue and redeem Government securities, administer the Treasury tax and loan accounts of commercial banks, and perform various other Government financial duties.

Acting as fiscal agent, the four offices of this bank in 1967 issued, exchanged, and redeemed 9.9 million United States Savings Bonds valued at $\$ 627$ million. The number of bonds handled rose 6.4 per cent from
1966 to 1967 , while dollar value declined 6.4 per cent. Other Government securities issued, serviced, and retired totaled 603 thousand, which was 9.3 per cent below a year earlier, and dollar value was down 5.5 per cent to $\$ 16.2$ billion.

\section{Other Operations}

\section{Lerdirg whd the Disconnt Rere}

Member banks may borrow from the Federal Reserve Banks either through discounts of eligible paper, or through advances on their own promissory notes secured by eligible paper, Government securities, or other collateral. The custom has developed of referring to both types of Reserve Bank lending to member banks as discounting, and the interest charge applicable to such lending is known as the discount rate. The discount rate is established by the bank's directors, subject to review and determination by the Board of Governors. The rate was adjusted twice during 1967, being reduced from $4 \%$ to 4 per cent in April and increased to $4 / 2$ per cent in November.

Borrowing by member banks from the Federal Reserve Bank of St. Louis during 1967 dropped sharply from year-earlier levels. Average credit outstanding to member banks in the Eighth District was $\$ 6$ million, down from $\$ 32$ million in 1966, but slightly above the average outstanding during the 1961-64 period.

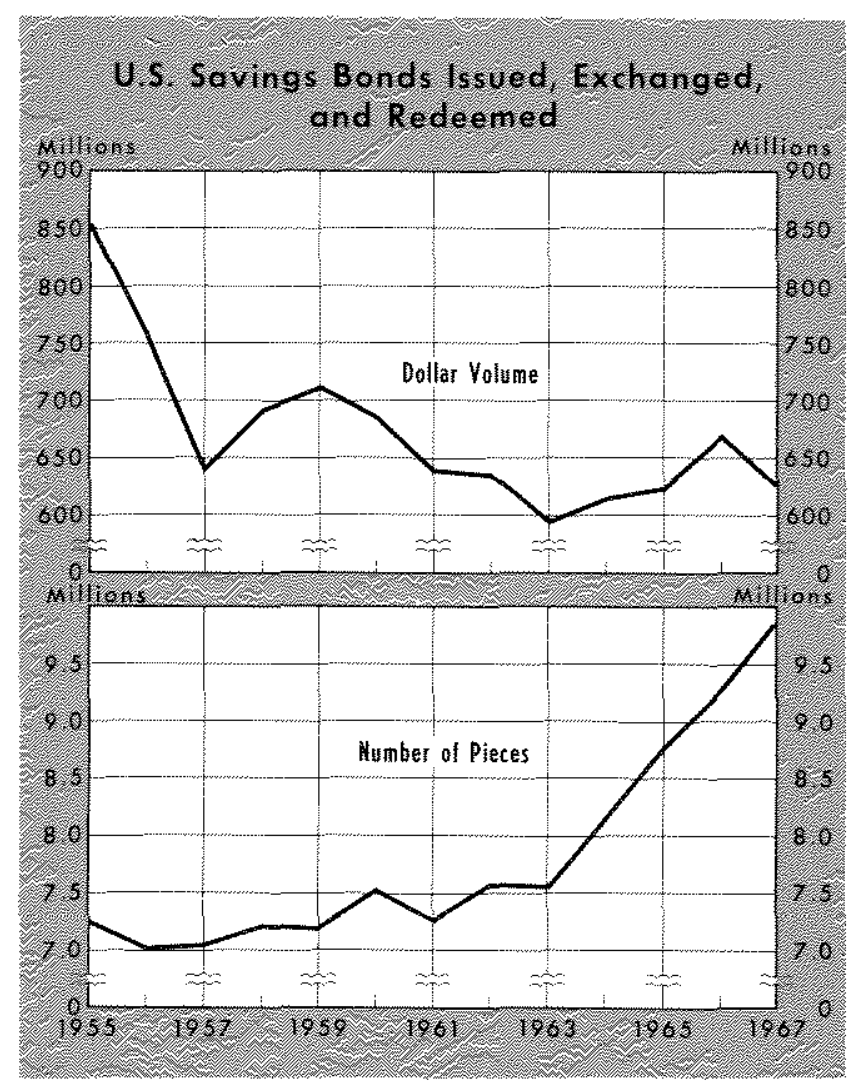




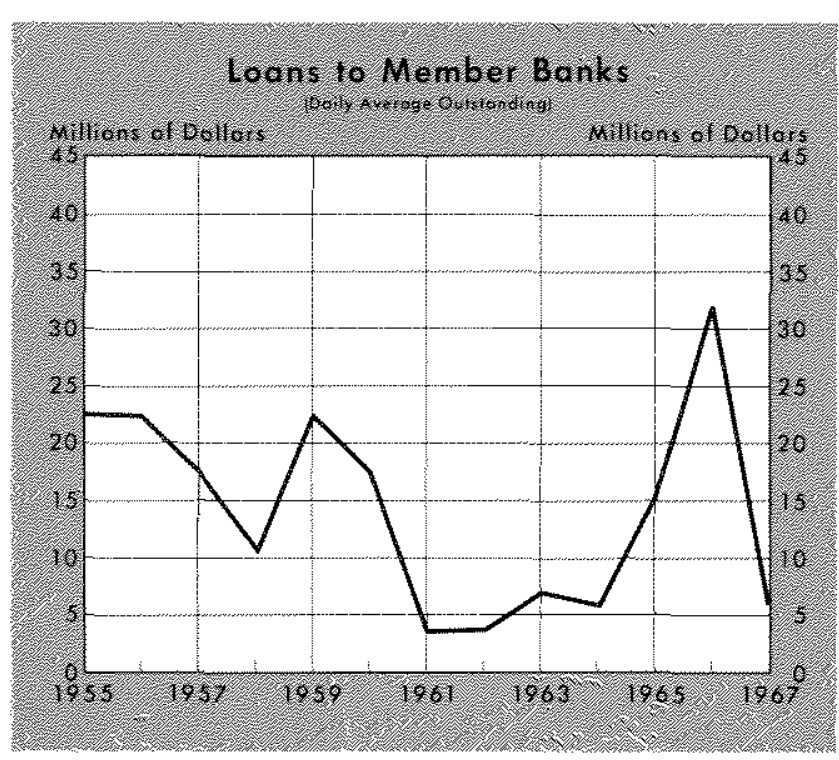

Saperasion and Examination

One function of the Federal Reserve System is to maintain effective supervision of commercial banks. The objective of such supervision is to foster and maintain a sound banking system.

A major supervisory responsibility is evaluation of assets, operations, policies, and the effectiveness of management of the banks subject to review. Examinations provide the basic information which enables supervisory authorities to contribute to prevention or correction of situations that might adversely affect the economy or the general public interest.

Supervision by the Federal Reserve Bank of St. Louis is exercised principally through examination of state member banks. The major objectives of these examinations are to develop information that will disclose the current financial condition of each bank and

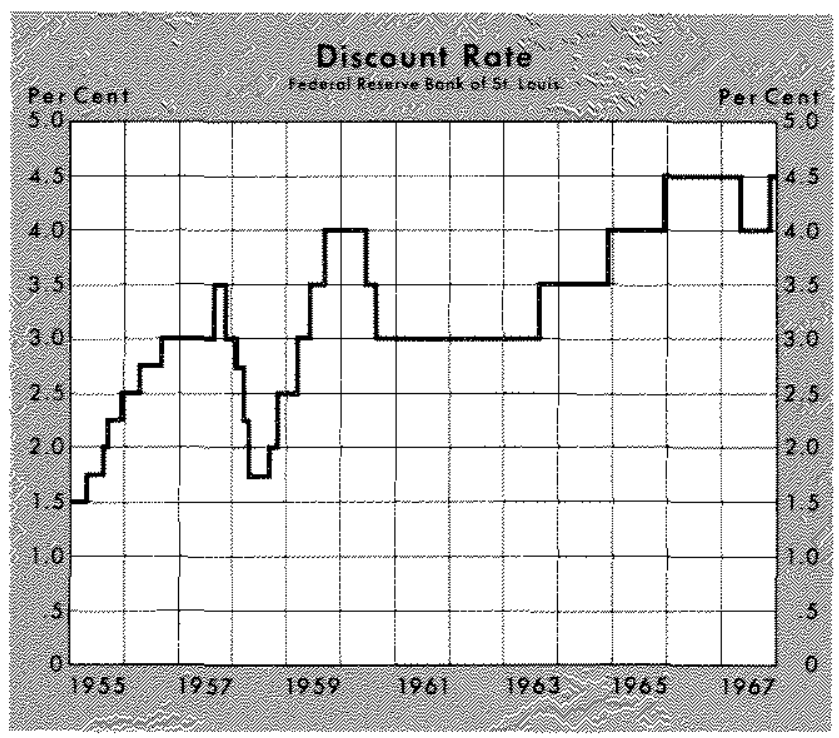

adequacy of its management; to ascertain whether the bank is complying with applicable laws and regulations; to evaluate the adequacy of its accounting methods, records system, and internal safeguards; and to indicate the bank's future operating prospects. Examinations were made of all state member banks in the district in 1967.

Other supervisory functions of the Federal Reserve System include admission of state banks to membership in the System; approval of the establishment of branches and merger or absorption of other banks by state member banks; and permission to establish bank

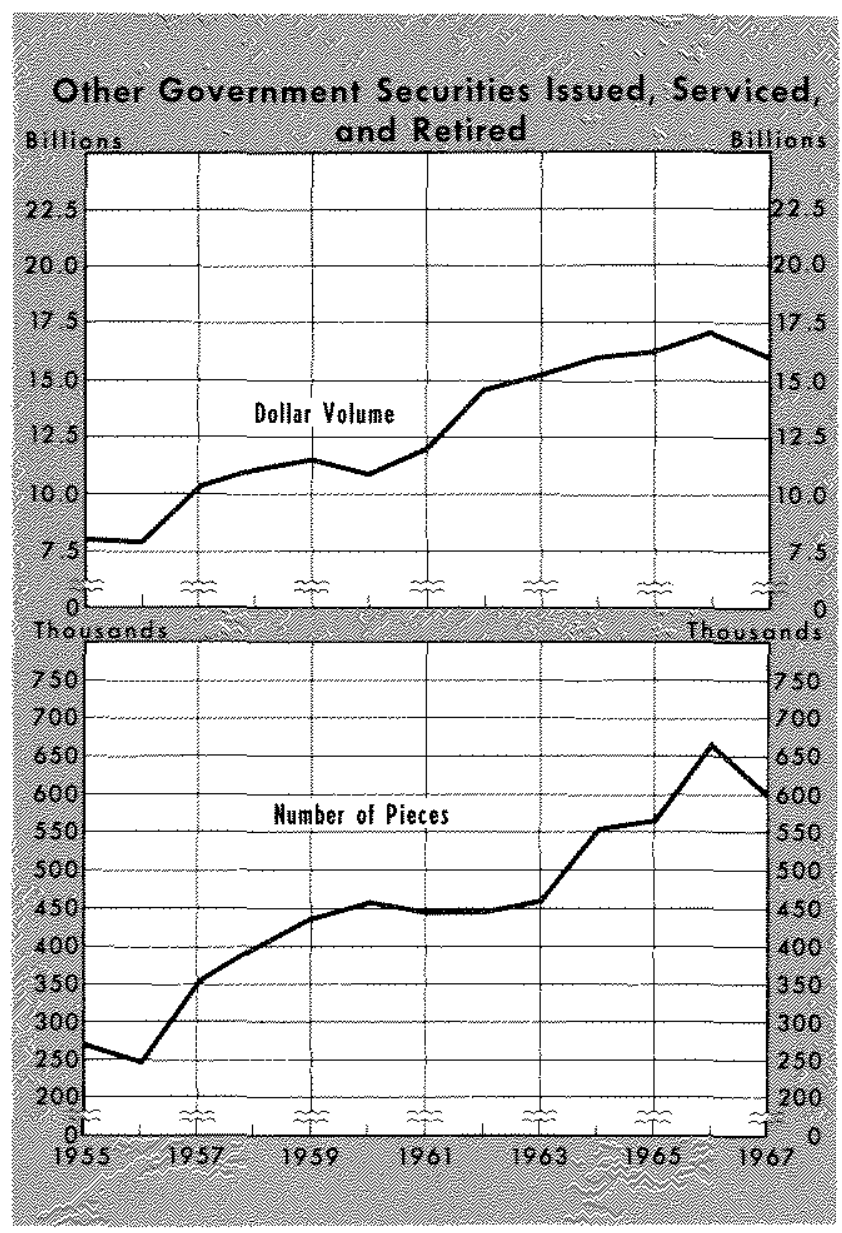

holding companies and for such companies to acquire stock in banks. Much of the fieldwork involved in such supervisory functions is conducted at the Reserve Banks. In addition, authority to approve domestic branches of state member banks and certain other supervisory functions is delegated to Reserve Banks.

\section{Resench}

Research operations at the Federal Reserve Bank of St. Louis are directed toward national business and financial problems. Analyses are conducted of both 


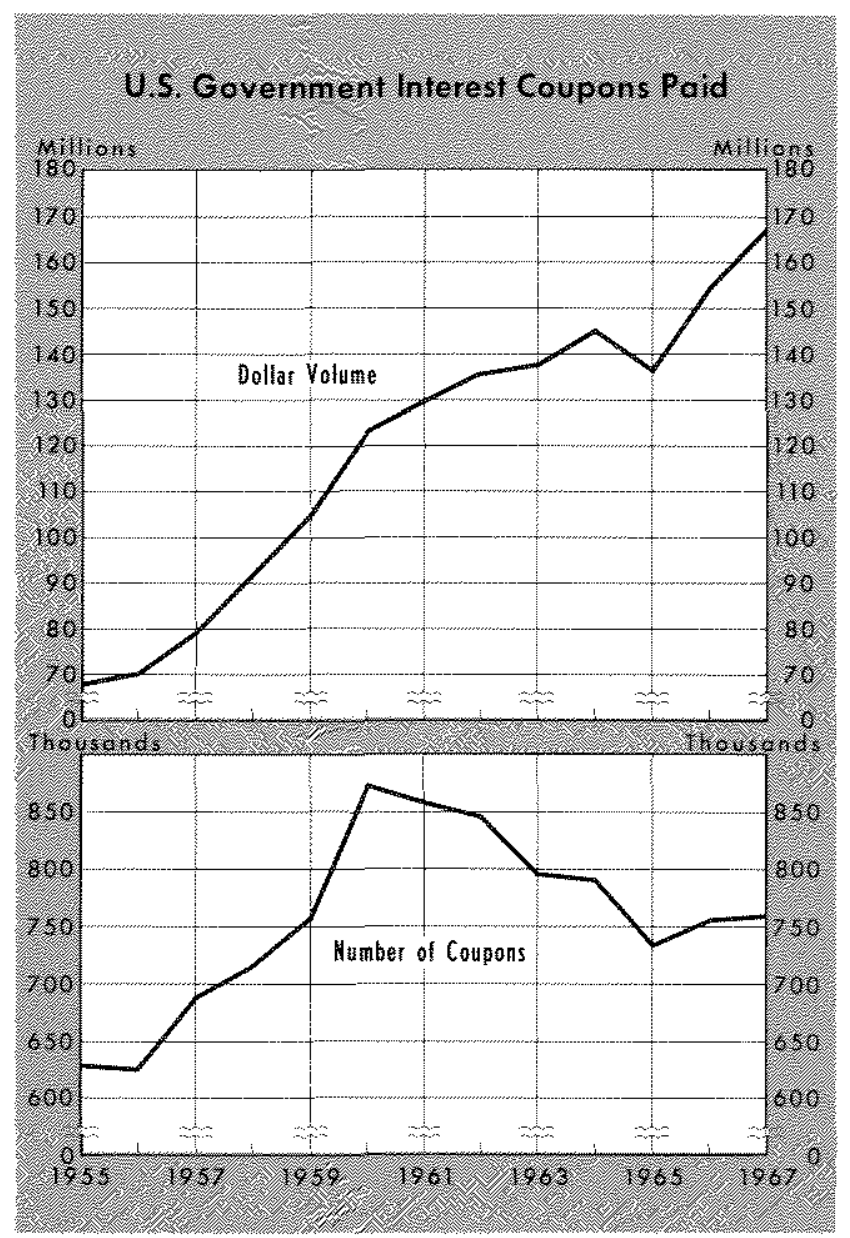

current economic problems and those of a more basic longer run nature. Also, efforts are made to measure and interpret economic developments in the Eighth Federal Reserve District. Such analyses are used to assist the President of the Bank in discharging his responsibilities as a participant in the Federal Open Market Committee deliberations, and in formulating his recommendations to the bank's Board of Directors. In addition, the research staff engages in activities to provide economic information to the public. This is accomplished through publication of the monthly Review and by various releases of economic data. These releases are made available to the public without charge and are listed on page 20 in this Review.

\section{Situtements}

As in most other recent years, the financial statements of the Federal Reserve Bank of St. Louis showed gains in 1967. Total assets were $\$ 2.85$ billion at the end of 1967, an increase of 9 per cent from a year earlier. A substantial rise in holdings of U. S. Government securities during the year more than offset declines in gold certificate reserves and discounts to member banks.
Holdings of U. S. Government securities result from the operations of the System Open Market Account. These open market operations, which are the major instrument of monetary policy, are authorized by the Federal Open Market Committee and are undertaken at the Federal Reserve Bank of New York by the Committee's agent. Although the securities remain at the New York bank, each Reserve Bank participates in the holdings and earnings of the System Account. At the end of 1967 holdings of U.S. Government Securities allocated to the Federal Reserve Bank of St. Louis

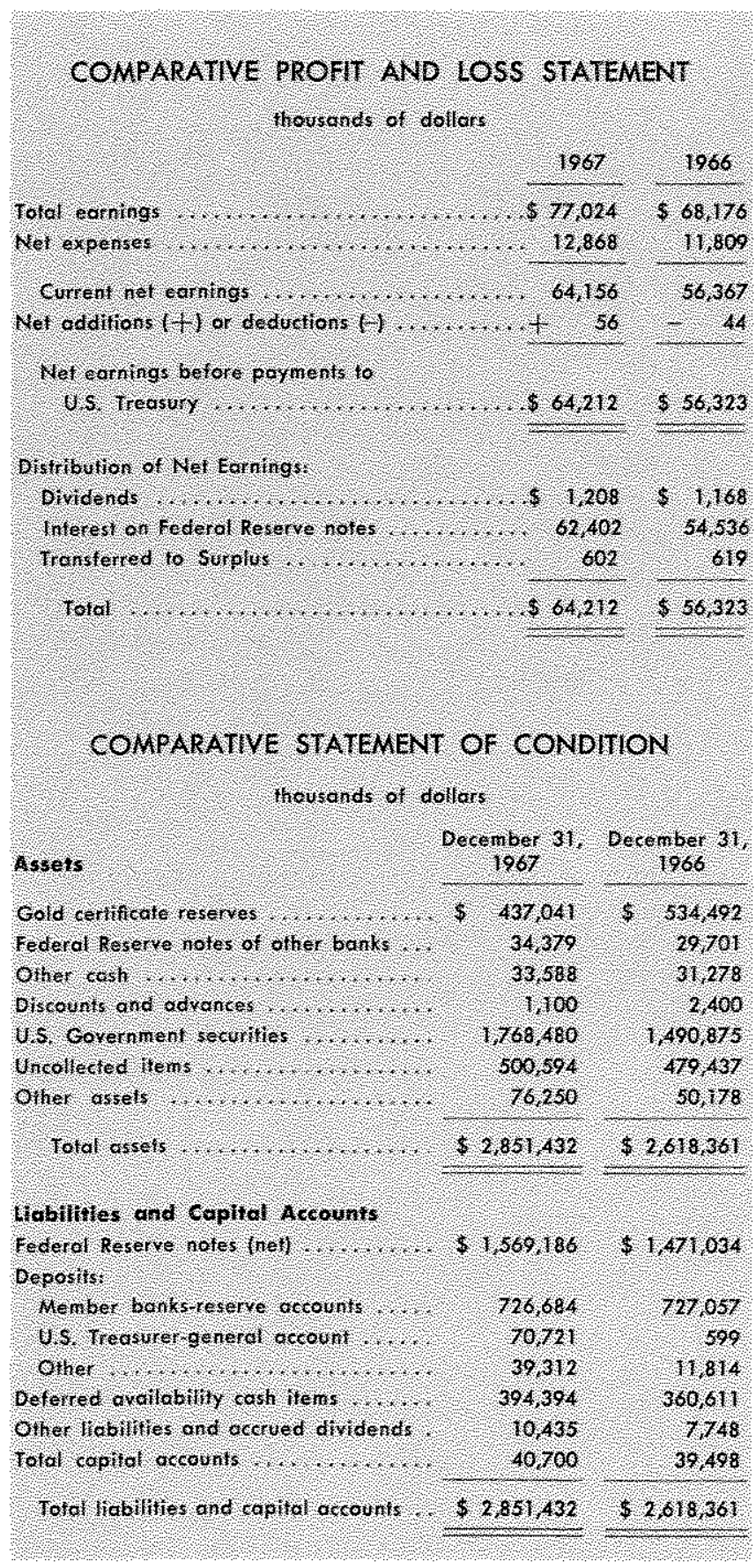


amounted to 3.6 per cent of System-wide holdings.

Net earnings before payments to the United States Treasury totaled $\$ 64$ million in 1967 , up 14 per cent from 1966. Dividends to member banks, set by law at 6 per cent of paid-in capital, were up 3.4 per cent.
After dividends and increases in surplus to equal paidin capital, net earnings are set aside for the U. S. Treasury as interest on Federal Reserve notes. Such payments totalled $\$ 62$ million in 1967 , up 14 per cent from a year earlier.

\footnotetext{
UBSCRIPTIONS to this bank's REviEw are available to the public without charge, including bulk mailings to banks, business organizations, educational institutions, and others. For information write: Research Department, Federal Reserve Bank of St. Louis, P. O. Box 442, St. Louis, Missouri 63166.
} 